\title{
Value Modeling for Ecosystem Analysis
}

\author{
Alejandro Arreola González ${ }^{1, *}$, Matthias Pfaff ${ }^{1}$ (D) and Helmut Krcmar ${ }^{2}$ \\ 1 Business Model \& Service Engineering, fortiss GmbH, 80805 Munich, Germany; bmse@fortiss.org \\ 2 Chair for Information Systems, Technical University of Munich, 80333 Munich, Germany; krcmar@in.tum.de \\ * Correspondence: gonzalez@fortiss.org; Tel.: +49-(89)-3603522-20
}

Received: 30 July 2019; Accepted: 11 September 2019; Published: 13 September 2019

\begin{abstract}
Scholars have proposed many approaches to represent and analyze value creation. Value creation in ecosystems such as platform ecosystems often relies on a specific structure of partner alignment. Value modeling techniques can improve the understanding of how ecosystem risks and non-generic complementarities determine value creation and the alignment structures required. First, we conceptualize ecosystem analysis as a tool for alignment in the context of business innovation. Then, we carry out a structured literature review to identify existing techniques, which could support ecosystem analysis. Further, we provide a comprehensive overview of the value modeling techniques and integrate our ecosystem analysis conceptualization with existing classification frameworks. This integrative framework allows researchers and scholars to identify techniques that suit specific needs in terms of internal alignment reach, tooling, innovation phase and ecosystem analysis. Our results show limited support for ecosystem analysis. Still we are able to identify techniques that can provide a useful conceptual or tooling basis to enable ecosystem analysis.
\end{abstract}

Keywords: value model; ecosystem; platform; alignment; tool

\section{Introduction}

Value modeling techniques enable the understanding, communication and analysis of value creation. Researchers and practitioners use well-established approaches such as e3value [1] and its tools [2] to analyze the profitability of value constellations from a multi-actor perspective. While value modeling in information systems and management science dates back at least to the mid-90s (cf. e.g., [3,4]), the socio-technical change caused in recent years by digital technologies [5], especially by digital platforms, has increased the focus of the analysis of value creation to the ecosystem of actors that forms around them [3]. In particular, the discipline of information systems proposes value modeling techniques and other business model representations to understand dependencies and enable alignment with other abstraction layers such as strategy or IT $[4,6]$. However, value creation in (platform) ecosystems relies on partner alignment structures $[7,8]$ and requires the understanding of ecosystem risks and complementarities. The analysis of ecosystem risks, however, is currently not supported by any value modeling technique or other business representation [9].

Digital platforms de-link assets from value, re-intermediate, and aggregate markets to disrupt business models and industry structures [10]. By enabling direct and indirect value co-creation, complex networks of innovation form around them, where business models intersect and interoperate across different players, calling for richer models that delineate interdependent ecosystems [11]. Researches study the relationships in these ecosystems and their implications for business model design of a platform, for example, to inform the relationship management with complementors [12]. To better understand how these and other elements impact the structure and dynamics of platform ecosystems and the business models involved, not only models but also software tools are needed [13].

Previous works in the domains of information systems, management science and engineering have proposed and applied different value modeling techniques to understand, communicate and 
analyze business models and ecosystems. Previous comprehensive literature reviews have provided a synthesizing framework and overview of existing techniques [14] as well as classified visualization techniques according to the cognitive functions and the phases of the business innovation process they support [15]. The purpose of this work is twofold: first, to integrate both existing classification frameworks so we can provide a comprehensive overview and, second, to examine how the analysis of value creation in ecosystems is supported with which existing value modeling techniques. We find that, despite the many value modeling techniques available, conceptual and tool support for ecosystem analysis is limited. We are able, however, to identify some techniques that could enable analyses that could lead to a better understanding of the alignment structures required to co-create value. The structure of the rest of the paper is as follows. In Section 2, we introduce the theoretical background on value modeling we use in this work. In Section 3, we explain our methodology in terms of search process and synthesis approach. We then present our results in Section 4, discuss and conclude in Section 5.

\section{Theoretical Background}

\subsection{Value Modeling and Business Model Representations}

Early business value models have been used to identify key performance measures and design variables for information technology [16] and to understand how to exploit complementarities to maximize organizational payoff [17]. With the increasing relevance of third parties in value creation, the modeling tools used by practitioners and researchers have evolved to analyze the increasing amount of firms involved in value creation [7]. Nowadays, researchers can pick from a pool of different value modeling approaches such as e3-value [1,18], SimulValor [19], Resource-event-agent [20], Value delivery meta model [21] or dynamic business model canvas [22], to name just a few, available to model and analyze ecosystems as well as understand the business models involved. Such approaches are also known as business model representations. Business model representations are defined as a mix of textual and graphical elements, or an ontology [23], used as tools for improving understanding, analysis, experimentation and for defining underlying information systems requirements [14]. Value modeling, in particular, depicts transfers of economic value that take place between the actors of a value constellation [24]. A value model shows which actors are involved and which objects of economic value are exchanged [25]. We use these definitions and consider value-modeling techniques to be a subcategory of business model representations that has to allow the modeling of multi-actor value creation. Value models of (platform) ecosystems can increase the odds of success when designing a platform and understanding the business models that will intersect through it to form an ecosystem. Some classification frameworks for business model representations have been proposed for ontologies [26], to provide a comprehensive overview [14], to differentiate between environmental and internal concepts [27], to differentiate types of value, flows and decision variables [28], and to differentiate content views and graphical forms [15].

\subsection{Business, Innovation and Platform Ecosystems}

Value creation in ecosystems has been discussed in the context of business, innovation and platform ecosystems. We discuss shortly these three because we understand platform ecosystems to be an innovation ecosystem that, in turn, shares the characteristics of a business ecosystem. Business ecosystems have been described as economic communities supported by a foundation of interacting organizations and individuals which coevolve their capabilities and roles, and tend to align themselves with the direction set by one or more central companies that enable members to move toward shared visions to align their investments, and to find mutually supportive roles [29]. For an innovation (business) ecosystem to be successful (i.e., achieve Pareto equilibrium) partners need to be aligned and design strategies to approach alignment around not only structure and roles but also around ecosystem risks, namely co-innovation and adoption chain risks [7]. Here, and for the rest of this work, alignment is understood as the extent to which there are compatible incentives and motives, as well as consistent 
activity configurations among the ecosystem partners [7]. Further, the specific alignment structures required to be able to create value are determined by non-generic unique and/or supermodular (i.e., more of A makes B more valuable) complementarities [8].

Value creation in ecosystems has also been described in the context of IT enabled business models (e.g., [30]) and, in particular, digital platforms. A platform ecosystem is comprised by a core technical platform and the apps that complement it [13,31]. Accordingly, the information technologies that ecosystem actors provide, such as application programming interfaces, are an important factor for cultivating a platform ecosystem [32]. Companies such as Google, Apple or Facebook use multisided business models to capture value from information involving the coordination of business models in networks of developers and content providers [11]. Digital platform ecosystems have proven disruptive in information-intensive industries ranging from mobile telecommunications (e.g., Android, iOS) to finance (e.g., PayPal, Apple Pay, Kickstarter) and mobility (e.g., Uber), to health care (e.g., PatientsLikeMe) [13].

\subsection{Ecosystem Strategy and Ecosystem Risks}

An ecosystem strategy is defined as the approach of a focal firm to the alignment of partners (e.g., complementors) which need to innovate or adopt an innovation for a value proposition to materialize [7]. This innovation or adoption need can be challenged by ecosystem risks. Successfully approaching the ecosystem risks that arise when co-innovation and adoption is required to create value, can lead to better partner alignment.

Co-innovation risk is defined as the challenge that partners face when developing the ability to undertake the new activities that underlie their planned contributions. Adoption chain risk as the partners' willingness to undertake the required activities, raising questions of priorities and incentives for participation [7]. We illustrate this in the context of digital platforms. A co-innovation risk could arise when a complementary service or application needs to be modified in order for a value proposition envisioned for a platform to materialize. An adoption chain risk would arise if a platform requires partners to share data in order for the platform to be able to capture value from a complimentary business intelligence services offered on the basis of that data. Successfully approaching these risks would bring these partners into roles and positions they are satisfied with (i.e., partner alignment), and which is required for value to be created or captured [7].

\subsection{Towards an Integrative Theoretical Framework}

Value models, specially business model representations, can be used to internally align strategy, business processes and IT/IS [4]. However, with the increasing number of actors involved in interdependent value creation as is the case in platform ecosystems, an external actor alignment structure becomes necessary. Ecosystem risks can endanger an interdependent value proposition and firms need to first be able to recognize them to then be able to create conditions for closing identified gaps (i.e., approach partner alignment) [7]. Besides the identification of ecosystem risks as an argument for the need of an alignment structure, we also want to consider the extent of the underlying complementarity (unique, supermodular or non-generic) [8]. Further, alignment between the ecosystem and the ideas generated for business model innovation to ensure external alignment happens during the initiation phase, which is the first iterative loop of the business innovation process [33]. Figure 1 provides an overview of a proposed integrative framework where ecosystem analysis, comprised by the analysis of ecosystem roles, structure, risks and complementarities can provide insights on how to approach the partner alignment needed to create value in ecosystems. Hence, with this integrative framework, we intend to extend the conceptualization of business model representations, specifically value modeling techniques, as tools not only for intra-organizational alignment, but as tools for inter-organizational alignment.

We briefly illustrate the proposed framework. An ecosystem actor might want to innovate its business model, therefore requiring a suitable representation depending on the innovation phase it finds itself in. Depending on the innovation, internal re-alignment between some of the strategy, 
business model, business process or IS/IT layers may be required. If external, inter-firm, alignment is needed, ecosystem roles can be analyzed using ontologies. Ecosystem structure can be analyzed using the positions and links of a value model. While the analysis of roles and structure can help to identify gaps in partner expectations, the analysis of ecosystem risks and the nature of complementarity enable a deeper understanding of alignment needs. Such an ecosystem analysis could improve the odds of success in aligning the partners and thus creating the necessary conditions for an ecosystem to thrive. In the next section, we build on this proposed framework to be able to categorize the techniques identified depending on their suitability for ecosystem analysis.

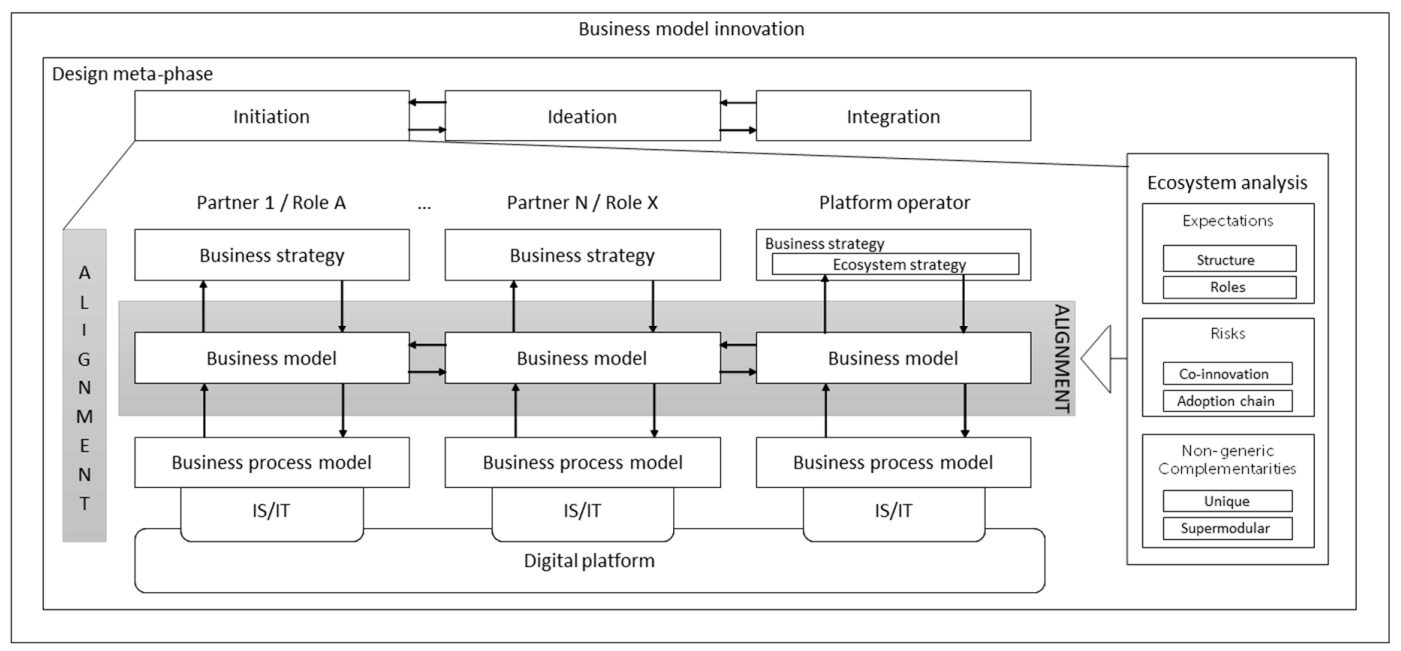

Figure 1. Ecosystem analysis to approach partner alignment in the initiation phase of the iterative process of business model innovation. (Source: own analysis, based on [4,7,8,33])

\section{Research Method}

\subsection{Literature Search Approach}

The review of the literature follows [34]. Although we only discuss in detail a selected sample of works that relate to the same concepts as we go about the implications in the next sections, we try to be exhaustive in our search as described next. To identify value modeling techniques, we build on the literature review on business model representations carried out by [14], focusing on the period after 2011 to update and extend their conceptualization and review. To identify relevant works, we performed a forward and a backward search for the value modeling techniques identified by them. We went forward by searching for articles that cited the articles identified in their review. Then we went backwards by reviewing the articles cited in the ones identified in the forward search. The database queried was Scopus, limited to the domains "computer science", "decision sciences", "business, management and accounting", as well as "engineering". To narrow down the results, the keywords "business model representation", "business model ontology", "business modeling" and "conceptual model" were searched for in the abstracts. We consequently performed the backward search based on the relevant works identified in the results of the previous step. Although Scopus results encompass only conference papers and journal articles, the backward search performed on the query results led us to include cited books and dissertations in our review as well.

\subsection{Literature Synhtesis Approach}

The works we identified at the end of the search process were categorized: (1) following [4], to provide a general overview; (2) following [15], according to their suitability for different business model innovation phases; and (3), following [7] and [8] respectively, whether they support the modeling of ecosystem risks, as well as the nature of complementarities. The classification framework presented in Table 1 provides an overview of existent value modeling techniques. We do this by integrating and 
extending two existing frameworks used to classify business model representations. In addition, to make our overview more understandable, we have grouped the works on the vertical axis according to the nature of the analysis they support: conceptual, heuristic, mathematic, ontological or stochastic. Next, we explain each of the dimensions and corresponding categories used on the vertical axis.

\subsubsection{Alignment, Perspective, Notation and Tooling}

We first include the dimensions and classes from the first comprehensive classification framework [14]: reach, perspective, notation principle and tool support. The reach differentiates between layers: strategy, business model, business process and IT/IS. The perspective can be either a single view or multiple views depending on specific aspects of a business model. The notation principle can be either map-based, like a spatially structured template, or network based, with different graphical notations depending on the concept. A map-based approach is suitable for describing large numbers of concepts, but less for depicting relationships between elements. A network-based notation is suitable to depict the complex networks that characterize platform ecosystems. Therefore, in our results we only include business model representations with a network-based approach, excluding those not fitting with the definition of value modeling presented before. Finally, the value modeling techniques can be just a formalization, or already implemented as a design or even a financial evaluation tool. Since we are not only interested in financial evaluation, but rather in experimentation-enabled innovation in general, we additionally categorize using the term "other evaluation" to include other types of analyses as well.

\subsubsection{Business Model Innovation and Cognitive Needs}

We also include the dimensions and classes from another comprehensive synthesizing effort carried out from a cognitive perspective [15]. In their review, the authors propose a classification framework according to the information transmitted (content) and the graphic form of the value modeling technique. They do this to identify which ones are more suitable, given a specific phase in the process of business model innovation. We accordingly show which view on value creation is available in the different techniques: elements, transactions or causality. The phase of business model innovation "initiation and integration", the authors argue, are best supported, respectively, by brainstorming webs with an elements view, by conceptual maps with causal or transactional views, and by graphic organizers with an elements view. We accordingly include the categories are brainstorming webs, conceptual maps and graphic organizers within the dimension graphic form. As mentioned above, ecosystem analysis usually takes place in the initiation phase of the process of business model innovation. Accordingly, in Table 1 we only include those business model representations that are conceptual maps that depict causality and/or transactions.

\subsubsection{Ecosystem Analysis}

Firms in ecosystems define their ecosystem strategy around a vision of structure, roles, and activity-based risks that arise from the partners' ability to undertake new activities (co-innovation) and from their willingness to adopt an innovation (adoption chain) [7]. Also platform ecosystems where participants have supermodular complementarities that are non-generic, require the creation of a specific structure of relationships and alignment to create value [8]. This dimension aims at assessing the usefulness of a value modeling technique in evaluating ecosystem risks and thus analyzing ecosystems. We categorize the dimension ecosystem analysis in activity configuration, to examine if partner dependence is explicit at this level. We also include categories for co-innovation and adoption risks, to examine if a given technique allows for the analysis of ecosystem risks. Further, in order to enable the modeling of the nature of complementarity, we include the categories unique, supermodular and non-generic to specify which techniques depict either of those types. 


\section{Results}

Table 1 shows the business model representations we identified as value modeling techniques. This means those with a network-based notation and appropriate for the initiation phase to support the configuration of value constellations. We classified the selected value modeling techniques using the dimensions and corresponding classes described in the previous section and sorted the works chronologically. In our search process, we identified in total 67 works proposing business model representations or extensions. Of these, 12 had already been identified by [14] and an additional 32 by [15]. For the sake of completeness, we show the remaining 31 representations that the literature search yielded, and we do not consider value-modeling techniques, in Table A1 of Appendix A.

Eight techniques reach from the business model layer only to the strategy layer. Only two reach from the business process through the business model up to the strategy layer: Eriksson-Penker business extensions [35] and e3value [1] with its extensions towards the strategy [36] and the process layer [37]. Only one [17] reaches from the strategy, through business model and process layers down to the IT/IS layer. 14 allow multiple views. Besides depicting actors, only three [21,22,28] explain causalities and allow insights on transactions. While most value modeling techniques are conceptual maps, only three [22,38,39] are also graphic organizers. Most of the value modeling techniques identified are rather formalized, which is a prerequisite for tooling. While 15 techniques also offer some kind tool support, only a handful (11) support evaluation.

Table 1. Overview of identified value modeling techniques and extensions. (Source: own analysis, based on $[7,8,14,15])$.

\begin{tabular}{|c|c|c|c|c|c|c|c|c|c|c|c|c|c|c|c|c|c|c|c|c|c|c|}
\hline \multirow[b]{3}{*}{ 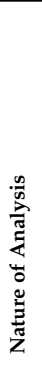 } & \multirow[b]{3}{*}{$\begin{array}{l}\text { Business Model } \\
\text { Representations } \\
\text { Considered Also Value } \\
\text { Modeling Techniques }\end{array}$} & \multicolumn{12}{|c|}{ General Overview } & \multicolumn{5}{|c|}{$\begin{array}{l}\text { Innovation Phase and } \\
\text { Cognitive Need Fit }\end{array}$} & \multicolumn{4}{|c|}{ Ecosystem Analysis } \\
\hline & & \multicolumn{4}{|c|}{$\begin{array}{c}\text { Internal } \\
\text { Alignment } \\
\text { Reach }\end{array}$} & \multicolumn{2}{|c|}{ Perspective } & \multicolumn{3}{|c|}{ Notation } & \multicolumn{3}{|c|}{ Tooling } & \multicolumn{3}{|c|}{ Content } & \multicolumn{2}{|c|}{$\begin{array}{l}\text { Graphic } \\
\text { Form }\end{array}$} & $\begin{array}{l}\text { Ecosystem } \\
\text { Risks }\end{array}$ & \multicolumn{3}{|c|}{ Complementarities } \\
\hline & & 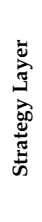 & 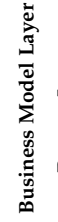 & 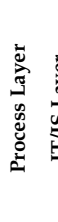 & 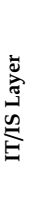 & $\begin{array}{l}\frac{0}{00} \\
5\end{array}$ & $\frac{0}{20}$ & 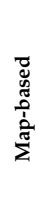 & 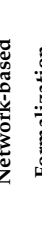 & . & Dี & 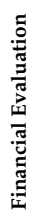 & 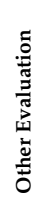 & 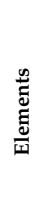 & 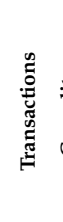 & 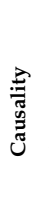 & 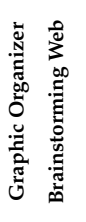 & 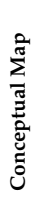 & 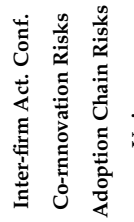 & 芯 & 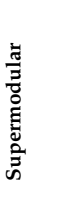 & 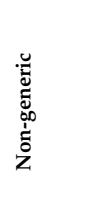 \\
\hline \multirow{10}{*}{ 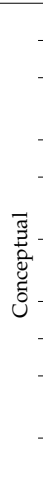 } & Activity system map [40] & $x$ & $x$ & & & $x$ & & & $x$ & & & & & & & $x$ & & $x$ & & & & \\
\hline & E3-value $[1,18]$ & & $x$ & & & $x$ & & & $x>$ & $x$ & $x$ & $x$ & $x$ & $x$ & $x$ & & & $x$ & & & & \\
\hline & $\begin{array}{l}\text { Eriksson-Penker business } \\
\text { extensions [35] }\end{array}$ & $x$ & $x$ & $x$ & & & $x$ & & $x>$ & $x$ & $x$ & & & & $x$ & & & $x$ & & & & \\
\hline & Value map $[41,42]$ & & $x$ & & & $x$ & & & $x$ & & & & & & $x$ & & & & & & & \\
\hline & $\begin{array}{l}\text { Operating business } \\
\text { model [43] }\end{array}$ & & $x$ & & & $x$ & & & $x>$ & $x$ & & & & $x$ & & $x$ & & $x$ & & & & \\
\hline & $\begin{array}{l}\text { E-business model } \\
\text { schematics [44] }\end{array}$ & & $x$ & & & $x$ & & & $x$ & & & & & $x$ & $x$ & & & $x$ & & & & \\
\hline & C3-value [36] & $\mathrm{x}$ & $x$ & & & & $x$ & & $x>$ & $x$ & & & & $x$ & $x$ & & & $x$ & & & & \\
\hline & Main virtuous circle [45] & & $x$ & & & $x$ & & & $x>$ & $x$ & & & & $x$ & & $x$ & & $x$ & & & & \\
\hline & $\begin{array}{l}\text { E-business model and } \\
\text { factors [46] }\end{array}$ & & $x$ & & & $x$ & & & $x>$ & $\mathrm{x}$ & & & & & $x$ & & & $x$ & & & & \\
\hline & $\begin{array}{l}\text { Business model for digital } \\
\text { content platforms [47] }\end{array}$ & & $x$ & & & $x$ & & & $x>$ & $x$ & & & & & $x$ & & & $x$ & & & & \\
\hline
\end{tabular}


Table 1. Cont

\begin{tabular}{|c|c|c|c|c|c|c|c|c|c|c|c|c|c|c|c|c|c|c|c|c|c|c|}
\hline \multirow[b]{3}{*}{ 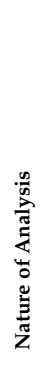 } & \multirow[b]{3}{*}{$\begin{array}{l}\text { Business Model } \\
\text { Representations } \\
\text { Considered Also } \\
\text { Value Modeling } \\
\text { Techniques }\end{array}$} & \multicolumn{12}{|c|}{ General Overview } & \multicolumn{5}{|c|}{$\begin{array}{l}\text { Innovation Phase and } \\
\text { Cognitive Need Fit }\end{array}$} & \multicolumn{4}{|c|}{ Ecosystem Analysis } \\
\hline & & \multicolumn{4}{|c|}{$\begin{array}{l}\text { Internal } \\
\text { Alignment } \\
\text { Reach }\end{array}$} & \multicolumn{2}{|c|}{ Perspective } & \multicolumn{3}{|c|}{ Notation } & \multicolumn{3}{|c|}{ Tooling } & \multicolumn{3}{|c|}{ Content } & \multicolumn{2}{|c|}{$\begin{array}{l}\text { Graphic } \\
\text { Form }\end{array}$} & $\begin{array}{l}\text { Ecosystem } \\
\text { Risks }\end{array}$ & \multicolumn{3}{|c|}{ Complementarities } \\
\hline & & 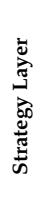 & 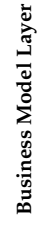 & 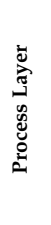 & 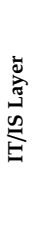 & $\begin{array}{l}\stackrel{0}{00} \\
\text { क }\end{array}$ & $\frac{0}{\frac{0}{2}}$ & 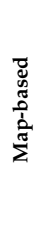 & 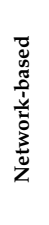 & 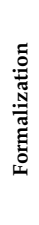 & 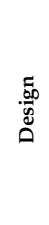 & 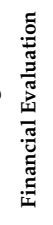 & 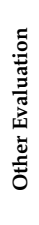 & 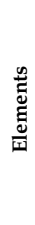 & 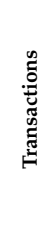 & 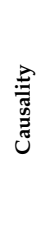 & 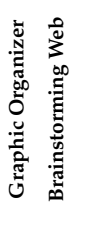 & 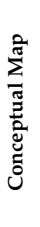 & 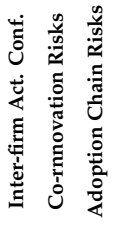 & & 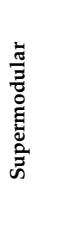 & 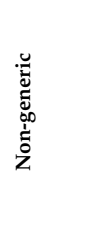 \\
\hline \multirow{13}{*}{ 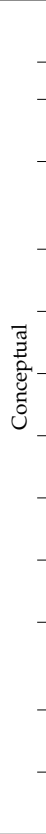 } & $\begin{array}{l}\text { Business model of } \\
\text { alliances [48] }\end{array}$ & & $\mathrm{x}$ & & & $x$ & & & $\mathrm{x}$ & $x$ & & & & $x$ & & $x$ & & $x$ & & & & \\
\hline & Value stream map [49] & $x$ & $x$ & & & $x$ & & & $x$ & & & & & $x$ & $x$ & & & & & & & \\
\hline & $\begin{array}{l}\text { Business model system } \\
\text { dynamics modules [50] }\end{array}$ & & $x$ & & & & $x$ & & $\mathrm{x}$ & $x$ & & & $\mathrm{X}$ & $x$ & & $x$ & & $\mathrm{x}$ & & & & \\
\hline & $\begin{array}{l}\text { Causal loop diagram of } \\
\text { e-Business model } \\
\text { ontology [51] }\end{array}$ & & $x$ & & & & & & $\mathrm{X}$ & $\mathrm{X}$ & & & & & & $\mathrm{X}$ & & $\mathrm{x}$ & & & & \\
\hline & $\begin{array}{l}\text { Causal loop } \\
\text { diagram [52] }\end{array}$ & $\mathrm{X}$ & $x$ & & & $x$ & & & $x$ & & & & & $x$ & & $\mathrm{x}$ & & $\mathrm{x}$ & & & & \\
\hline & $\begin{array}{l}\text { Dynamic structure of } \\
\text { business models [53] }\end{array}$ & & $x$ & & & $x$ & & & $x$ & $x$ & $\mathrm{X}$ & $\mathrm{x}$ & $x$ & & & $\mathrm{X}$ & & $\mathrm{X}$ & & & & \\
\hline & $\begin{array}{l}\text { Depiction of a business } \\
\text { model [ } 54]\end{array}$ & & $x$ & & & $x$ & & & $\mathrm{x}$ & $x$ & & & & $x$ & & $x$ & & & & & & \\
\hline & $\begin{array}{l}\text { [moby]business model } \\
\text { ontology [39] }\end{array}$ & & $x$ & & & & $x$ & & $\mathrm{x}$ & $x$ & $\mathrm{X}$ & $\mathrm{x}$ & & $x$ & & $x$ & $x$ & $\mathrm{x}$ & & & & \\
\hline & $\begin{array}{l}\text { Trading business } \\
\text { model [55] }\end{array}$ & & $x$ & & & $\mathrm{X}$ & & & $\mathrm{x}$ & $x$ & & & & & $x$ & & & $\mathrm{X}$ & & & & \\
\hline & $\begin{array}{l}\text { Business model causal } \\
\text { loop diagram [56] }\end{array}$ & & $x$ & & & $x$ & & & $\mathrm{X}$ & $x$ & & & & & & $\mathrm{X}$ & & $x$ & & & & \\
\hline & $\begin{array}{l}\text { Business model extract } \\
\text { in the system dynamics } \\
\text { notation [57] }\end{array}$ & & $x$ & & & & $x$ & $x$ & $\mathrm{x}$ & $x$ & & $\mathrm{x}$ & $x$ & $x$ & & $x$ & & $\mathrm{x}$ & & & & \\
\hline & $\begin{array}{l}\text { Dynamic business } \\
\text { model canvas [22] }\end{array}$ & & $x$ & & & & $x$ & $\mathrm{X}$ & $x$ & $x$ & $\mathrm{X}$ & & $x$ & $x$ & $x$ & $\mathrm{X}$ & $X$ & $\mathrm{x}$ & & & & \\
\hline & $\begin{array}{l}\text { Value-based process } \\
\text { model design [37] }\end{array}$ & & $x$ & $\mathrm{X}$ & & & $x$ & & $\mathrm{X}$ & $x$ & $\mathrm{X}$ & $x$ & $x$ & $x$ & $x$ & & & $\mathrm{X}$ & & & & \\
\hline 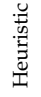 & E3tool [24] & & $x$ & & & & $x$ & & $x$ & & $\mathrm{X}$ & $\mathrm{x}$ & $x$ & $x$ & $x$ & & & $\mathrm{x}$ & & & & \\
\hline \multirow{3}{*}{ 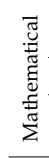 } & $\begin{array}{l}\text { Value model of } \\
\text { reengineering [17] }\end{array}$ & $x$ & $x$ & $x$ & $\mathrm{X}$ & $\mathrm{X}$ & & & $x$ & $x$ & & & & $x$ & & $x$ & & $\mathrm{x}$ & & & $x$ & \\
\hline & SimulValor [19] & & $x$ & & & & $x$ & & $x$ & $x$ & $x$ & $x$ & $\mathrm{X}$ & $x$ & & $x$ & & $x$ & & & & \\
\hline & $\begin{array}{l}\text { Modified } \\
\text { SimulValor [28] }\end{array}$ & $\mathrm{X}$ & $x$ & & & $x$ & & & $x$ & $x$ & $X$ & & $\mathrm{X}$ & $x$ & $x$ & $x$ & & $\mathrm{x}$ & $\mathrm{x}$ & & & \\
\hline \multirow{3}{*}{$\begin{array}{l}\widetilde{3} \\
80 \\
\frac{0}{0} \\
0 \\
0\end{array}$} & $\begin{array}{l}\text { B4U design } \\
\text { framework [58] }\end{array}$ & & $x$ & & & $x$ & & & $x$ & $x$ & & & & $x$ & & $x$ & & & & & & \\
\hline & $\begin{array}{l}\text { Description model for } \\
\text { internet-based business } \\
\text { models [38] }\end{array}$ & & $x$ & & & $x$ & & $x$ & $x$ & $x$ & $\mathrm{X}$ & & & $x$ & $x$ & & $x$ & $\mathrm{x}$ & & & & \\
\hline & $\begin{array}{l}\text { Reference ontology for } \\
\text { business models [59] }\end{array}$ & & $x$ & & & & $x$ & & $x$ & $x$ & $x$ & & & $x$ & & $x$ & & $\mathrm{X}$ & & & & \\
\hline \multirow{6}{*}{$\begin{array}{l}\bar{J} \\
\frac{0}{00} \\
\frac{0}{0} \\
0 \\
0 \\
0\end{array}$} & $\begin{array}{l}\text { Reference ontology for } \\
\text { business models [59] }\end{array}$ & & $x$ & & & & $x$ & & $x$ & $x$ & $\mathrm{X}$ & & & $x$ & & $x$ & & $\mathrm{X}$ & & & & \\
\hline & $\begin{array}{l}\text { Strategic business } \\
\text { model ontology [60] }\end{array}$ & $x$ & $x$ & & & & $x$ & & $x$ & $x$ & $X$ & & & $x$ & & $x$ & & & & & & \\
\hline & $\begin{array}{l}\text { Relationships of } \\
\text { business model } \\
\text { elements [61] }\end{array}$ & & $x$ & & & $x$ & & & $x$ & $x$ & & & & & & $x$ & & $x$ & & & & \\
\hline & $\begin{array}{l}\text { Resource-event-agent } \\
{[20]}\end{array}$ & & $x$ & & & & $x$ & & $x$ & $x$ & $\mathrm{X}$ & & & & $\mathrm{X}$ & & & $\mathrm{x}$ & & & & \\
\hline & $\begin{array}{l}\text { Multi-level business } \\
\text { model ontology [27] }\end{array}$ & $x$ & $x$ & & & & $x$ & & $x$ & $x$ & & & & $x$ & & & & $\mathrm{x}$ & & & & \\
\hline & $\begin{array}{l}\text { Value delivery } \\
\text { metamodel [21] }\end{array}$ & $x$ & $x$ & & & & $x$ & & $x$ & & & & & $x$ & $x$ & $\mathrm{X}$ & & $\mathrm{x}$ & $x$ & & & \\
\hline 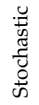 & $\begin{array}{l}\text { E3-value + real } \\
\text { options [62] }\end{array}$ & & $x$ & & & $x$ & & & $x$ & $x$ & & $\mathrm{x}$ & $x$ & $x$ & $x$ & & & $\mathrm{X}$ & & & & \\
\hline
\end{tabular}


Kundisch et al. [14] had already shown which business model representations could be used for structure and roles. Täuscher and Abdelkafi [15] showed which ones to use taking the cognitive challenges of specific phases of the business model innovation process. We expected that, as platform ecosystems and the way the firms involved strategically approach it, become increasingly relevant for the business models involved, ecosystem risks and the nature of complementarities would be depicted by techniques available. To find out if the value modeling techniques available can be effectively used to analyze digital platform ecosystems, we built on ecosystem theory. Specifically, on theory developments that point at ecosystem risks [7] and the nature of complementarity [8] as some of the main determinants of an ecosystem alignment structure and, therefore, of an ecosystem strategy. Table 1 shows limited possibilities to analyze ecosystems from the ecosystem risk and the complementarity perspectives. Nevertheless, it allows to identify techniques that could provide insights on how to model activity-level interdependence, which can be used to model ecosystem risks. Inter-firm activity configuration is explicit in two techniques [21,28], while none currently takes the ecosystem risks introduced above into account. Also, the table allows us to identify one technique which could provide insights on how to model supermodularity of complementarities [17].

\section{Discussion and Conclusions}

\subsection{Enabling Support for Ecosystem Analysis}

Given the increasing relevance of platform ecosystems and their relation to the business models involved, we believe that value-modeling techniques can be useful explanatory, design and evaluation tools. The overview provided should further enable cumulative research, as researchers are able to identify suitable techniques and build on available concepts and tools. While there are many approaches proposing modeling concepts, far less approaches focus on ontological or mathematical analysis. Only one approach identified uses heuristic analysis while another allows stochastic analysis. Future research might try to include new heuristics to automate analyses, while many stochastic methods remain unexplored in this domain. Further, we are able to show the shortcomings that the techniques available have when compared to late developments in ecosystem theory. From all the works we reviewed, those that make partner interdependence explicit at the activity level and those that model supermodular complementarities in their representation offer insights on how ecosystem analysis might be enabled.

The overview provided can be used to identify existing value modeling techniques that best suit a certain alignment or innovation purpose, to conceptually extend it, and even implement ecosystem risk or complementarity analysis in a software tool. To enable ecosystem analysis as conceptualized here, we identify existent techniques which could be enhanced or serve as a conceptual basis. The modified SimulValor [28] or the value delivery metamodel [21] depict activity-level interdependence and could therefore serve as a conceptual basis to enable ecosystem risk analysis. From a tooling perspective, due to its sound scientific foundations, documentation and availability, e3value [63] with its e3tool [2,64], which already supports advanced fraud risk analysis, can be a good basis to support ecosystem risk analysis. Regarding the nature of complementarities, the concepts presented by [17] shed some light on how to model supermodular complementarities, which, especially since it reaches down to the IS/IT layer, is very valuable to analyze the socio-technical systems that platform ecosystems are. A good basis for extensions, from an internal alignment perspective, could be business extensions [35], business engineering meta model [65] or e3-value [1], which has a rich family of conceptual and tool extensions (see e.g., [36,37,62,66-68]).

\subsection{Avenues of Future Research}

Future research could extend existing concepts and tools such those of e3-value framework to make interdependence explicit at the activity or transaction level. Together with the analysis of structure and roles, ecosystem risk analysis and complementarity modeling can enable the design of better ecosystem 
strategies. Researchers could then assess the dynamics of the alignment structure that specific business model designs of platforms require. Ecosystem risks and the nature of complementarities could be included as new determinants of the performance of business model design in such contexts where interdependence plays an essential role. To enable agile and informed business model design, software tool extensions that support the analysis of the impact of interdependence on profit or value could be implemented. Advanced risk analysis functionalities such as sensitivity analysis and methods for automated model generation, as proposed by [24], could be used to evaluate external or inter-firm alignment structures. Thus, we see a promising avenue of research in the evaluation, maybe using the ecosystem analysis concepts reviewed here, of the partner alignment structures embedded in platform value models.

Existing variables and processes criteria could be combined to developed new hybrid ecosystem theory contributions. New explainable variables for ecosystem alignment could also be drawn from empirical or design science research aiming at validating the effectivity of value modeling techniques as design, explanatory or evaluation tools. This could extend current design theory of value modeling or platform ecosystem theory and contribute to their understanding. Further, formal semantics, theorems and proofs are still needed to increase rigor with axioms in most value modeling techniques identified. Formalization can in turn lead to some automation for entering information in value modeling tools or for translating from there to other tools (cf. [69]). One example is the automated translation of a value model into more concrete elements such as organizational structures (e.g., departments, units, human re-sources), business processes (e.g., workflows (responsibilities) and IT/IS architectures [70].

\subsection{Limitations}

We limit our conceptualization of ecosystem analysis to the analysis of ecosystem roles, structure ans risks [7] together with the concept of non-generic unique or supermodular complementarity [8]. We use these concepts as criteria against which we hold up the value modeling techniques we identified. As an argument of sufficiency, although not completeness, other authors [31,71] also see the need to deal with these same risks. Also, although complementarity in value modeling is not new [17], the conceptualization of non-generic unique or supermodular complementarity is relatively new [8]. We recognize that further criteria to assess the suitability of value modeling techniques for ecosystem analysis could be identified in platform, innovation or business ecosystem theory we did not cover here. While research areas such as enterprise modeling and supply chain management intersect with some of the concepts and objectives discussed here, [28] for example, compare some enterprise modeling languages with the purpose of modeling a value network, and opt for a value modeling technique because, they do not include a value perspective. Regarding tool support, supply chain management literature, which we did not cover here, could provide complementing insights when it comes to simulation methods. Further, our classification does not go into detail regarding simulation methods used by the works identified. Some of the value modeling techniques and representations identified use methods such as system dynamics, agent-based or discrete event simulation to model the relationships between concepts. Since the concepts in each work identified themselves give a specific, not equal, meaning to the concepts of the underlying simulation method (e.g., the stocks, flows and causal loops of the system dynamics method), we differentiate the works identified depending on the value-creating concepts that are modelled using e.g., system dynamics concepts. Future research may try to synthesize modeling techniques by looking at the simulation methods and concepts used.

\subsection{Conclusion}

Value modeling could be valuable for the design of platform business models that are characterized by ecosystem interdependencies. To examine to which extent the techniques currently available fulfill this promise, we carried out a literature review. We updated and, by conceptualizing ecosystem analysis, extended previous literature reviews on business model representations since they covered value-modeling techniques as well. We integrate their conceptualizations with ecosystem theory 
concepts to add a new determinant of business models design: ecosystem analysis, which is comprised by the analysis of ecosystem roles, structure, risks and complementarities. Using this extended conceptual framework, we examined to which extent value modeling techniques currently support ecosystem analysis. The overview we provide serves a foundation with which researchers and practitioners can identify suitable value modeling techniques and tools, depending on specific internal or external alignment needs. We could only identify very limited concepts and tools available to enable ecosystem analysis. Nevertheless, we could identify some techniques that provide some conceptual or tooling basis for ecosystem analysis and provide insight for future research on possible extensions of existing techniques.

Author Contributions: Conceptualization, A.A.G., M.P.; methodology, formal analysis, investigation, resources, data curation, writing-original draft preparation, writing-review and editing, and visualization, A.A.G.; supervision, M.P.; project administration, H.K.

Funding: This research received no external funding.

Conflicts of Interest: The authors declare no conflict of interest.

\section{Appendix A}

Table A1. Overview of business model representations and extensions identified, excluding the representations presented as value modeling techniques in Table 1. (Source: own analysis, based on $[7,8,14,15])$.

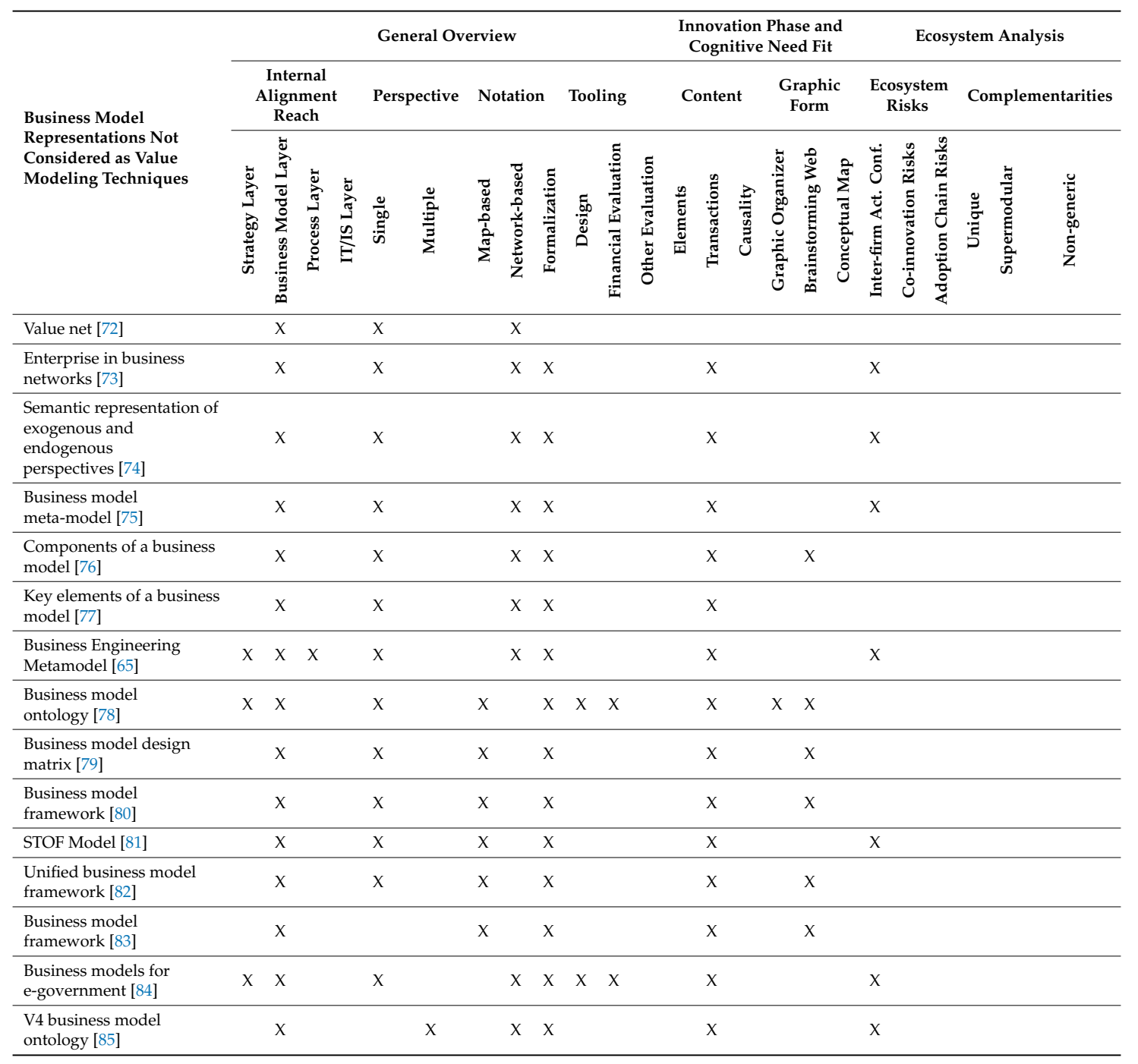


Table A1. Cont.

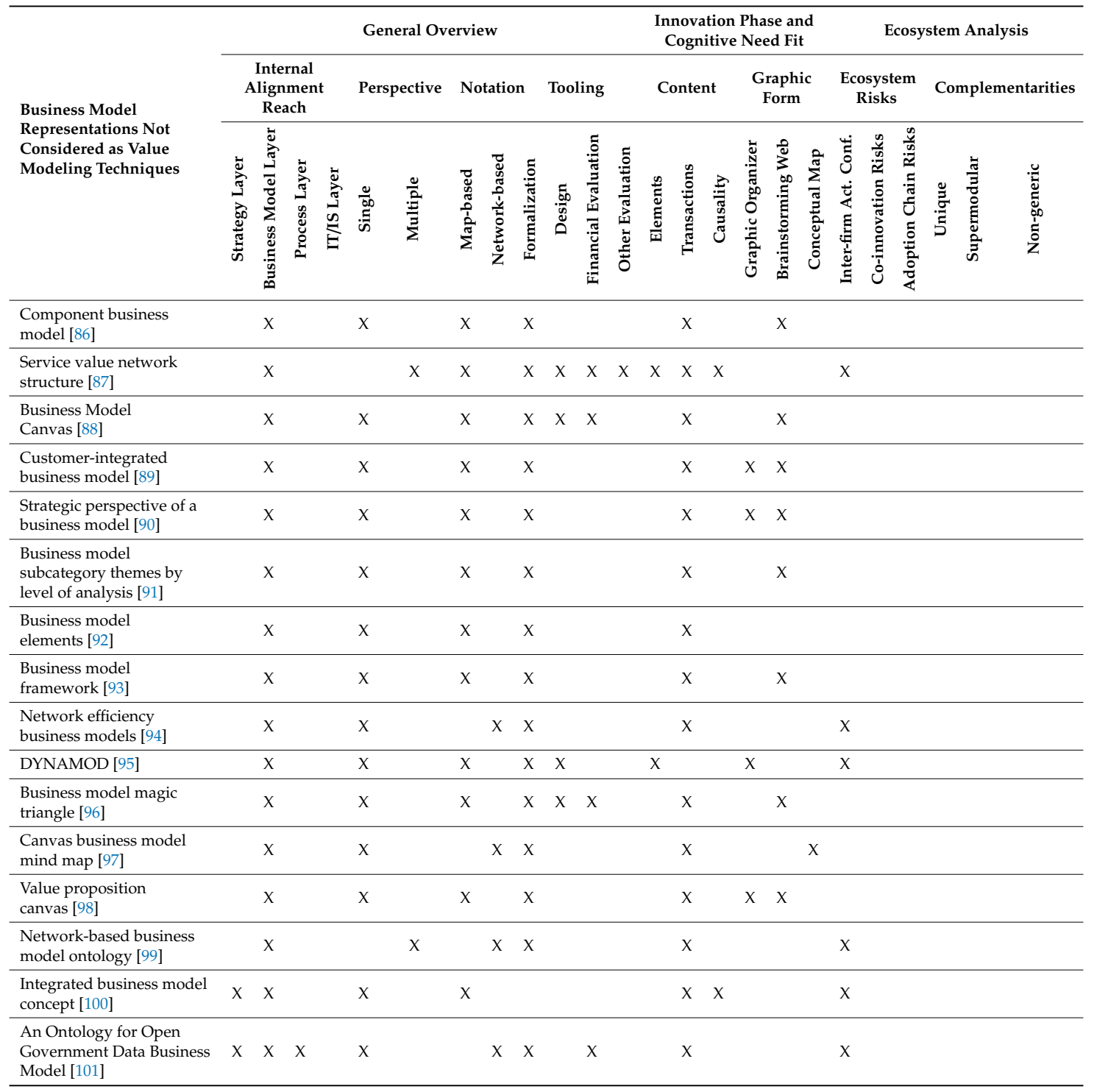

\section{References}

1. Gordijn, J.; Akkermans, H. E3-Value: Design and Evaluation of e-Business Models. IEEE Intell. Syst. 2001, 16, 11-17. [CrossRef]

2. Gordijn, J.; Ionita, D.; Rubbens, B.; Wieringa, R. E3tools: Toolkit for Building and Analyzing Networked Business Models. 2016.

3. Parker, G.; Van Alstyne, M.; Jiang, X. Platform Ecosystems: How Developers Invert the Firm. MIS Q. 2017, 41, 255-266. [CrossRef]

4. Al-debei, M.M.; Avison, D. Developing a Unified Framework of the Business Model Concept. Eur. J. Inf. Syst. 2010, 19, 359-376. [CrossRef]

5. Arreola González, A.; Becker, K.; Cheng, C.-H.; Döricht, V.; Duchon, M.; Fehling, M.; von Grolman, H.; Hallensleben, S.; Hopf, S.; Ivandic, N.; et al. Digital Transformation: How Information and Communication Technology Is Fundamentally Changing Incumbent Industries; Fortiss GmbH: Munich, Germany, 2016. [CrossRef]

6. Veit, D.; Clemons, E.; Benlian, A.; Buxmann, P.; Hess, T.; Kundisch, D.; Leimeister, J.M.; Loos, P.; Spann, M. Business Models: An Information Systems Research Aagenda. Bus. Inf. Syst. Eng. 2014, 6, 45-53. [CrossRef]

7. Adner, R. Ecosystem as Structure: An Actionable Construct for Strategy. J. Manag. 2017, 43, 39-58. [CrossRef]

8. Jacobides, M.G.; Cennamo, C.; Gawer, A. Towards a Theory of Ecosystems. Strateg. Manag. J. 2018, 39, 2255-2276. [CrossRef] 
9. Arreola González, A.; Pfaff, M.; Krcmar, H. Business Model Representations and Ecosystem Analysis: An Overview. In Information Systems. EMCIS 2018. Lecture Notes in Business Information Processing; Themistocleous, M., Rupino da Cunha, P., Eds.; Springer: Cham, Switzerland, 2019; Volume 341, pp. 464-472.

10. Parker, G.G.; Van Alstyne, M.W.; Choudary, S.P. Platform Revolution: How Networked Markets Are Transforming the Economy and How to Make Them Work for You; W. W. Norton \& Company: New York, NY, USA, 2016; ISBN 0393249131.

11. Bharadwaj, A.; El Sawy, O.A.; Pavlou, P.A.; Venkatraman, N. Digital Business Strategy: Toward a Next Generation of Insights. MIS Q. 2013, 37, 471-482. [CrossRef]

12. Giessmann, A.; Legner, C. Designing Business Models for Cloud Platforms. Inf. Syst. J. 2016, 26, 551-579. [CrossRef]

13. De Reuver, M.; Sørensen, C.; Basole, R.C. The Digital Platform: A Research Agenda. J. Inf. Technol. 2018, 33, 124-135. [CrossRef]

14. Kundisch, D.; John, T.; Honnacker, J.; Meier, C. Approaches for Business Model Representation: An Overview. In Multikonferenz Wirtschaftsinformatik; Mattfeld, D.C., Robra-Bissantz, S., Eds.; TU Braunschweig: Braunschweig, Germany, 2012; pp. 1839-1850.

15. Täuscher, K.; Abdelkafi, N. Visual Tools for Business Model Innovation: Recommendations from a Cognitive Perspective. Creat. Innov. Manag. 2017, 26, 160-174. [CrossRef]

16. Weill, P. The Relationship between Investment in Information Technology and Firm Performance: A Study of the Valve Manufacturing Sector. Inf. Syst. Res. 1992, 3, 307-333. [CrossRef]

17. Barua, A.; Lee, C.H.S.; Whinston, A.B. The Calculus of Reengineering. Inf. Syst. Res. 1996, 7, 409-428. [CrossRef]

18. Gordijn, J.; Akkermans, J.M. Value-Based Requirements Eengineering: Exploring Innovative E-Commerce Ideas. Requir. Eng. 2003, 8, 114-134.

19. Elhamdi, M. Modélisation et Simulation de Chaînes de Valeurs En Entreprise-Une Approche Dynamique Des Systèmes et Aide à La Décision; École Centrale Paris: SimulValor, Paris, 2005.

20. Sonnenberg, C.; Huemer, C.; Hofreiter, B.; Mayrhofer, D.; Braccini, A. The REA-DSL: A Domain Specific Modeling Language for Business Models. In Proceedings of the 23rd International Conference on Advanced Information Systems Engineering, London, UK, 20-24 June 2011; pp. 252-266.

21. Object Management Group. Value Delivery Metamodel; Object Management Group: Needham, MA, USA, 2015; p. 140.

22. Cosenz, F. Supporting Start-up Business Model Design through System Dynamics Modelling. Manag. Decis. 2017, 55, 57-80. [CrossRef]

23. Zott, C.; Amit, R.; Massa, L. The Business Model: Recent Developments and Future Research. J. Manag. 2011, 37, 1019-1042.

24. Ionita, D.; Gordijn, J.; Yesuf, A.S.; Wieringa, R. Quantitative, Value-Driven Risk Analysis of e-Services. J. Inf. Syst. 2018. [CrossRef]

25. Gordijn, J. A Design Methodology for Modeling Trustworthy Value Webs. Int. J. Electron. Commer. 2018, 9, 31-48. [CrossRef]

26. Gordijn, J.; Osterwalder, A.; Pigneur, Y. Comparing Two Business Model Ontologies for Designing E-Business Models and Value Constellations. In Proceedings of the 18th Bled eConference eIntegration in Action, Bled, Slovenia, 6-8 June 2005; p. 17.

27. Burkhart, T.; Wolter, S.; Schief, M.; Krumeich, J.; Di Valentin, C.; Werth, D.; Loos, P.; Vanderhaeghen, D. A Comprehensive Approach towards the Structural Description of Business Models. In Proceedings of the International Conference on Management of Emergent Digital EcoSystems; ACM: New York, NY, USA, 2012; pp. 88-102. [CrossRef]

28. Daaboul, J.; Castagna, P.; Da Cunha, C.; Bernard, A. Value Network Modelling and Simulation for Strategic Analysis: A Discrete Event Simulation Approach. Int. J. Prod. Res. 2014, 52, 5002-5020. [CrossRef]

29. Moore, J.F. The Death of Competition: Leadership and Strategy in the Age of Business Ecosystems; HarperCollins: New York, NY, USA, 1996.

30. Rai, A.; Tang, X. Information Technology-Enabled Business Models: A Conceptual Framework and a Coevolution Perspective for Future Research. Inf. Syst. Res. 2014, 25, 1-14. [CrossRef]

31. Tiwana, A. Platform Ecosystems: Aligning Architecture, Governance, and Strategy; Morgan Kaufmann: Waltham, MA, USA, 2014. 
32. Ghazawneh, A.; Henfridsson, O. Balancing Platform Control and External Contribution in Third-Party Development: The Boundary Resources Model. Inf. Syst. J. 2013, 23, 173-192. [CrossRef]

33. Frankenberger, K.; Weiblen, T. The 4l-Framework of Business Model Innovation: A Structured View on Process Phases and Challenges. Int. J. Prod. Dev. 2013, 18, 249-273. [CrossRef]

34. Webster, J.; Watson, R.T. Analyzing the Past to Prepare for the Future: Writing a Literature Review. MIS Q. 2002, 5, xii.

35. Eriksson, H.; Penker, M. Business Modeling with UML; John Wiley \& Sons: New York, NY, USA, 2000.

36. Weigand, H.; Johannesson, P.; Andersson, B.; Bergholtz, M.; Edirisuriya, A.; Ilayperuma, T. Strategic Analysis Using Value Modeling-The C3-Value Approach. In Proceedings of the 2007 40th Annual Hawaii International Conference on System Sciences, Waikoloa, HI, USA, 3-6 January 2007; p. 175c.

37. Hotie, F.; Gordijn, J. Value-Based Process Model Design. Bus. Inf. Syst. Eng. 2019, 61, 163-180. [CrossRef]

38. Breuer, S. Beschreibung von Geschäftsmodellen Internetbasierter Unternehmen-Konzeption, Umsetzung, Anwendung. Ph.D. Thesis, University St. Gallen, St. Gallen, Switzerland, 2004.

39. Weiner, N.; Weisbecker, A. A Business Model Framework for the Design and Evaluation of Business Models in the Internet of Services. In Proceedings of the 2011 Annual SRII Global Conference, San Jose, CA, USA, 29 March-2 April 2011; pp. 21-33. [CrossRef]

40. Porter, M.E. What Is Strategy? Har. Bus. Rev. 1996, 74, 61-78. [CrossRef]

41. Allee, V. Reconfiguring the Value Network. J. Bus. Strategy 2000, 21, 36-39. [CrossRef]

42. Tapscott, D.; Ticoll, D.; Lowy, A. Digital Capital; Harvard Business School Press: Boston, MA, USA, 2000.

43. Linder, J.; Cantrell, S. Changing Business Models: Surveying the Landscape; Accenture Institute for Strategic Change Conducts: Cambridge, MA, USA, 2000.

44. Vitale, M.; Weill, P. Place to Space: Migrating to Ebusiness Models; Harvard Business Review Press: Boston, MA, USA, 2001.

45. Casadesus-Masanell, R.; Ricart, J.E. Competing Through Business Models (No. D/713); IESE Business School: Madrid, Spain, 2007.

46. Horsti, A. Essays on Electronic Business Models and Their Evaluation; Helsinki School of Economics: Helsinki, Finland, 2007.

47. Poel, M.; Renda, A.; Ballon, P. Business Model Analysis as a New Tool for Policy Evaluation: Policies for Digital Content Platforms. info 2007, 9, 86-100. [CrossRef]

48. Seelos, C.; Mair, J. Profitable Business Models and Market Creation in the Context of Deep Poverty: A Strategic View. Acad. Manag. Perspect. 2007, 21, 49-63. [CrossRef]

49. Pynnonen, M.; Hallikas, J.; Savolainen, P. Mapping Business: Value Stream-Based Analysis of Business Models and Resources in Information and Communications Technology Service Business. Int. J. Bus. Syst. Res. 2008, 2, 305. [CrossRef]

50. Grasl, O. Business Model Analysis_Method and Case Studies; University of St. Gallen: St. Gallen, Switzerland, 2009.

51. Kiani, B.; Gholamian, M.R.; Hamzehei, A.; Hosseini, S.H. Using Causal Loop Diagram to Achieve a Better Understanding of E-Business Models. Int. J. Electron. Bus. Manag. 2009, 7, 159-167.

52. Casadesus-Masanell, R.; Ricart, J.E. From Strategy to Business Models and onto Tactics. Long Range Plan. 2010, 43, 195-215. [CrossRef]

53. Lerch, C.; Selinka, G. Dynamics of Business Models: Long-Ranging Impact Assessment of Business Models in the Capital Goods Industry. In Proceedings of the 28th International Conference of the System Dynamics Society, Seoul, Korea, 25-29 July 2010; p. 13.

54. Casadesus-Masanell, R.; Ricart, J.E. How to Design a Winning Business Model. Harvard Bus. Rev. 2011, 89, 100-107.

55. Velu, C.; Stiles, P. Managing Decision-Making and Cannibalization for Parallel Business Models. Long Range Plan. 2013, 46, 443-458. [CrossRef]

56. Täuscher, K.; Abdelkafi, N. Business Model Robustness: A System Dynamics Approach. In Proceedings of the 15th EURAM Conference, Warsaw, Poland, 17-20 June 2015; pp. 1-40.

57. Groesser, S.N.; Jovy, N. Business Model Analysis Using Computational Modeling: A Strategy Tool for Exploration and Decision-Making. J. Manag. Control 2016, 27, 61-88. [CrossRef] 
58. Faber, E.; Ballon, P.; Bouwman, H.; Haaker, T.; Rietkerk, O.; Steen, M. Designing Business Models for Mobile ICT Services. In Proceedings of the 16th Bled Electronic Commerce Conference eTransformation, Bled, Slovenia, 9-11 June 2003; p. 14.

59. Andersson, B.; Bergholtz, M.; Edirisuriya, A.; Ilayperuma, T.; Johannesson, P.; Grégoire, B.; Schmitt, M.; Dubois, E.; Abels, S.; Hahn, A.; et al. Towards a Common Ontology for Business Models. CEUR Workshop Proc. 2006, 200. [CrossRef]

60. Samavi, R.; Yu, E.; Topaloglou, T. Strategic Reasoning about Business Models: A Conceptual Modeling Approach. Inf. Syst. E-Bus. Manag. 2008, 7, 171-198. [CrossRef]

61. Schallmo, D.; Brecht, L. Business Model Innovation in Business-to-Business Markets-Procedure and Examples. In Proceedings of the 3rd ISPIM Innovation Symposium: "Managing the Art of Innovation: Turning Concepts into Reality", Quebec City, QC, Canada, 12-15 December 2010; pp. 1-24.

62. Kundisch, D.; John, T. Business Model Representation Incorporating Real Options: An Extension of E3-Value. In Proceedings of the 2012 45th Hawaii International Conference on System Sciences, Maui, HI, USA, 4-7 January 2012; pp. 4456-4465. [CrossRef]

63. Gordijn, J.; Akkermans, H. Value Webs: Understanding e-Business Innovation, 1st ed.; The Value Engineers B.V.: Soest, Germany, 2018.

64. Ionita, D.; Wieringa, R.J.; Gordijn, J. Automated Identification and Prioritization of Business Risks in E-Service Networks. Lect. Notes Bus. Inf. Process. 2016, 247, 547-560. [CrossRef]

65. Österle, H.; Blessing, D. Business Engineering Modell. In Business Engineering; Österle, H., Winter, R., Eds.; Springer: Berlin/Heidelberg, Germany; New York, NY, USA, 2003; pp. 65-85. [CrossRef]

66. Wieringa, R.; Gordijn, J.; Ionita, D. Tool Support for Value Modeling and Risk Analysis of E-Services. In Proceedings of the 24th Joint International Conference on Requirements Engineering: Foundation for Software Quality Workshops, Doctoral Symposium, REFSQ-JP 2018, Utrecht, The Netherlands, 19 March 2018.

67. Kartseva, V. Designing Controls for Network Organization: A Value-Based Approach. Ph.D. Thesis, Vrije Universiteit Amsterdam, Amsterdam, The Netherlands, 2007.

68. Kartseva, V.; Gordijn, J.; Tan, Y. Toward a Modeling Tool for Designing Control Mechanisms for Network Organizations. Int. J. Electron. Commer. 2005, 10, 57-84. [CrossRef]

69. Uschold, M.; Jasper, R.; Benjamins, V.R.; Chandrasekaran, B.; Gomez-Perez, A.; Guarino, N. A Framework for Understanding and Classifying Ontology Applications. In Proceedings of the IJCAI-99 Workshop on Ontologies and Problem-Solving Methods (KRR5), Stockholm, Sweden, 2 August 1999; pp. 1-11.

70. Brews, P.J.; Tucci, C.L. Internetworking: Building Internet-Generation Companies. Acad. Manag. Exec. 2003, 17, 8-24. [CrossRef]

71. Venkatraman, V.N.; El Sawy, O.A.; Pavlou, P.; Bharadwaj, A. Theorizing Digital Business Innovation: Platforms and Capabilities in Ecosystems. Fox School Bus. Res. Pap. 2014. [CrossRef]

72. Parolini, C. The Value Net: A Tool for Competitive Strategy, 1st ed.; Wiley: Milan, Italy, 1999.

73. Österle, H.; Fleisch, E.; Alt, R. Business Networking: Shaping Enterprise Relationships on the Internet, 2nd ed.; Springer: Berlin/Heidelberg, Germany, 2001; Volume 5.

74. Heinrich, B. Das Geschäftsmodell Als Instrument Zur Positionierung Des Unternehmens. In Retail Banking im Informationszeitalter-Integrierte Gestaltung der Geschäfts-, Prozess- und Applikationsebene; Leist, S., Winter, R., Eds.; Springer: Berlin, Germany, 2002; pp. 53-72.

75. Markus, B. Zur Herleitung von Geschäftsmodellen Für Finanzdienstleistungsunternehmen. Methode Und Fallbeispiele. Ph.D. Thesis, University St. Gallen, St. Gallen, Switzerland, 2003.

76. Hedman, J.; Kalling, T. The Business Model Concept: Theoretical Underpinnings and Empirical Illustrations. Eur. J. Inf. Syst. 2003, 12, 49-59. [CrossRef]

77. Voelpel, S.C.; Leibold, M.; Tekie, E.B. The Wheel of Business Model Reinvention: How to Reshape Your Business Model to Leapfrog Competitors; 03-10; Hitotsubashi University Institute of Innovation Research: Tokyo, Japan, 2003.

78. Osterwalder, A. The Business Model Ontology a Proposition in a Design Science Approach. Ph.D. Thesis, Université de Lausanne, Lausanne, Switzerland, 2004. [CrossRef]

79. Ballon, P. Business Modelling as the Configuration of Control and Value. In Proceedings of the 20th Bled eConference eMergence: Merging and Emerging Technologies, Processes, and Institutions, Bled, Slovenia, 3-6 June 2007; pp. 1-15. [CrossRef] 
80. Kamoun, F. Rethinking the Business Model with RFID. Commun. Assoc. Inf. Syst. 2008, 22, $635-658$. [CrossRef]

81. Bouwman, H.; Faber, E.; Haaker, T.; Kijl, B.; De Reuver, M. Mobile Service Innovation and Business Models; Bouwman, H., de Vos, H., Haaker, T., Eds.; Springer: Heidelberg, Germany, 2008; pp. 31-70. [CrossRef]

82. Goethals, F. The Unified Business Model Framework; Lille Economie Management: Lille, France, 2009.

83. Shi, Y.; Manning, T. Understanding Business Models and Business Model Risks. J. Priv. Equity 2009, 12, 49-59. [CrossRef]

84. Peinel, G.; Jarke, M.; Rose, T. Business Models for EGovernment Services. Electron. Gov. Int. J. 2010, 7, 380-401. [CrossRef]

85. Al-Debei, M.M.; Fitzgerald, G. The Design and Engineering of Mobile Data Services: Developing an Ontology Based on Business Model Thinking. In IFIP Working Conference on Human Benefit through the Diffusion of Information Systems Design Science Research; Springer: Berlin/Heidelberg, Germany, 2010; pp. 28-51. [CrossRef]

86. Chesbrough, H. Business Model Innovation: Opportunities and Barriers. Long Range Plan. 2010, 43, 354-363. [CrossRef]

87. Kijl, B.; Nieuwenhuis, B. Deploying a Telerehabilitation Service Innovation: An Early Stage Business Model Engineering Approach. In Proceedings of the 43rd Hawaii International Conference on System Sciences, Honolulu, HI, USA, 5-8 January 2010. [CrossRef]

88. Osterwalder, A.; Pigneur, Y. Business Model Generation; Wiley: New York, NY, USA, 2010.

89. Plé, L.; Lecocq, X.; Angot, J. Customer-Integrated Business Models: A Theoretical Framework. Management 2010, 13, 226-265. [CrossRef]

90. Weiner, N.; Renner, T.; Kett, H. Geschäftsmodelle Im Internet Der Dienste; Fraunhofer-Verlag: Stuttgart, Germany, 2010; Volume 64.

91. George, G.; Bock, A.J. The Business Model in Practice and Its Implications for Entrepreneurship Research. Entrep. Theory Pract. 2011, 35, 83-111. [CrossRef]

92. Mason, K.; Spring, M. The Sites and Practices of Business Models. Ind. Mark. Manag. 2011, 40, $1032-1041$. [CrossRef]

93. Abdelkafi, N.; Makhotin, S.; Posselt, T. Business Model Innovations for Electric Mobility-What Can Be Learned from Existing Business Model Patterns? Int. J. Innov. Manag. 2013, 17, 1-41. [CrossRef]

94. Chatterjee, S. Simple Rules for Designing Business Models. Calif. Manag. Rev. 2013, 55, 97-124. [CrossRef]

95. Zutshi, A.; Grilo, A.; Jardim-Goncalves, R. DYNAMOD: A Modelling Framework for Digital Businesses Based on Agent Based Modeling. In Proceedings of the 2013 IEEE International Conference on Industrial Engineering and Engineering Management, Bangkok, Thailand, 10-13 December 2013; pp. 1372-1376.

96. Gassmann, O.; Frankenberger, K.; Csik, M. The St. Gallen Business Model Navigator. Int. J. Prod. Dev. 2013, 18, 249-273.

97. Gavrilova, T.; Alsufyev, A.; Yanson, A.-S. Transforming Canvas Model: Map Versus Table. Int. J. Knowl. Innov. Entrep. Vol. 2014, 2, 51-65.

98. Osterwalder, A.; Pigneur, Y.; Bernarda, G.; Smith, A. Value Proposition Design, 1st ed.; Wiley: Hoboken, NJ, USA, 2014.

99. Nekoo, A.R.H.; Ashourizadeh, S.; Zarei, B. Designing Network-Based Business Model Ontology. Int. J. Netw. Virtual Organ. 2015, 15, 299-318. [CrossRef]

100. Wirtz, B.W.; Pistoia, A.; Ullrich, S.; Göttel, V. Business Models: Origin, Development and Future Research Perspectives. Long Range Plan. 2015, 49, 36-54. [CrossRef]

101. Zeleti, F.A.; Ojo, A. An Ontology for Open Government Data Business Model. In Proceedings of the 10th International Conference on Theory and Practice of Electronic Governance, New Delhi, India, 7-9 March 2017; pp. 195-203. [CrossRef]

(C) 2019 by the authors. Licensee MDPI, Basel, Switzerland. This article is an open access article distributed under the terms and conditions of the Creative Commons Attribution (CC BY) license (http://creativecommons.org/licenses/by/4.0/). 